\title{
Biologic Agents in Rheumatoid Arthritis: An Update for Managed Care Professionals
}

\author{
Sandeep K. Agarwal, MD, PhD
}

\begin{abstract}
BACKGROUND: Rheumatoid arthritis (RA) is a chronic, systemic autoimmune inflammatory arthritis that clinically manifests as joint pain, stiffness, and swelling. If left untreated, persistent synovial inflammation can progress to cartilage and bone destruction and ultimately to major longterm disability and mortality. Synthetic disease-modifying antirheumatic drugs (DMARDs), such as methotrexate, leflunomide, and sulfasalazine, have markedly improved clinical symptoms and slowed joint damage in RA patients. However, despite the effectiveness of synthetic DMARDs, many patients who use them continue to have clinical symptoms of inflammation and progressive joint destruction. Recent advances in our understanding of the pathogenesis of RA have led to the identification of novel cellular and molecular therapeutic targets. Biologic agents aimed at these targets have provided some evidence of effectiveness that is transforming the management of RA.
\end{abstract}

OBJECTIVE: To inform health care providers about some of the recent advances in RA pathogenesis and innovative biologic therapies that have shown effectiveness in improving clinical outcomes and inhibiting radiographic progression.

SUMMARY: Although the specific trigger of the autoimmune response in RA is not known, pathogenesis is generally believed to be associated with the generation of autoantibodies through interactions of antigen-presenting cells with the adaptive immune system ( $C D 4+T$ cells and $B$ cells). The main inflammatory mediators of joint inflammation and destruction in RA are tumor necrosis factor (TNF)-alpha, interleukin-1 (IL-1), IL-6, chemokines, and proteases. Advances in our understanding of the key cells and inflammatory cytokines have led to the development of targeted biologic agents. As of 2011, 5 TNF-alpha inhibitors are approved for use by the FDA: infliximab, etanercept, adalimumab, golimumab, and certolizumab pegol. In randomized clinical trials, all of these agents have been shown to be effective in reducing clinical signs of inflammation in RA patients who have failed synthetic DMARDs. Multiple studies have demonstrated significant benefits of early treatment with TNF-alpha inhibitors combined with methotrexate. Other FDA-approved biologic agents for treating moderate-tosevere RA include abatacept, rituximab, and tocilizumab. All biologic agents carry an increased risk of infections. Additional potential side effects include infusion and injection site reactions for intravenous and subcutaneously administered agents, respectively. All patients being considered for biologic agents should be screened annually for tuberculosis and should receive pneumococcal, influenza, and hepatitis $B$ vaccinations.

J Manag Care Pharm. 2011;17(9-b):S14-S18

Copyright $\odot 2011$, Academy of Managed Care Pharmacy. All rights reserved.
$\mathrm{R}$ heumatoid arthritis (RA) is a chronic, systemic autoimmune inflammatory arthritis that clinically manifests as joint pain, stiffness, and swelling. ${ }^{1}$ Without treatment, persistent inflammation leads to cartilage damage, bone erosions, and joint destruction, the major causes of long-term disability. Treatment with synthetic disease modifying antirheumatic drugs (DMARDs) such as methotrexate, leflunomide and sulfasalazine represented an important paradigm shift that resulted in marked improvement in clinical symptoms and slowing joint damage. ${ }^{2-8}$ However, despite the effectiveness of these medications in the treatment of RA patients, a significant number of patients continue to have clinical symptoms of inflammation and progressive joint destruction. Fortunately, recent advances in our understanding of the pathogenesis have led to the identification of novel therapeutic targets. Biologic agents aimed at these cellular and molecular targets have further transformed the management of RA. In this article we will provide a focused update on the biologic agents that are used in the treatment of RA.

\section{Pathophysiology of Joint Inflammation in Rheumatoid Arthritis}

RA is an inflammatory arthritis that results from a systemic autoimmune response. Although the specific trigger of the autoimmune response is not known, it is commonly believed that the generation of autoantibodies through interactions of the innate immune system (antigen-presenting cells) with the adaptive immune system (CD4 + T cells and B cells) is central to the pathogenesis. ${ }^{1,9}$ The systemic autoimmune response subsequently targets the synovial membrane. The normal synovial membrane lines the joint capsule of diarthrodial joints and is characterized by a thin lining layer made up of synovial fibroblasts and macrophages that rests upon a relatively hypocellular sublining layer, containing blood vessels, connective tissue, and a few immune cells such as mast cells and neutrophils. The inflamed synovial membrane in rheumatoid arthritis demonstrates cellular hyperplasia and activation in the lining layer and pronounced infiltration of inflammatory cells, including CD4+ T cells, B cells, plasma cells, macrophages, and neutrophils, into the sublining layer. The inflammatory infiltrate secretes large amounts of inflammatory cytokines, such as tumor necrosis factor (TNF)-alpha, interleukin-1 (IL1), IL-6, chemokines (chemoattractant cytokines that recruit additional cells), and proteases. ${ }^{10}$ These factors further activate the synovial lining macrophages and fibroblasts to secrete additional inflammatory cytokines and proteases. The end result is the formation of an inflamed and invasive synovial membrane called the pannus. The invasive pannus instigates joint destruction through cartilage degradation and activation 
Biologic Agents in Rheumatoid Arthritis: An Update for Managed Care Professionals

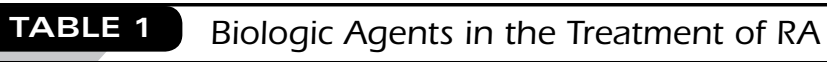

\begin{tabular}{|c|c|c|c|c|c|}
\hline Medication & Type of Biologic Agent & Target & $\begin{array}{c}\text { Route of } \\
\text { Administration }\end{array}$ & $\begin{array}{l}\text { Loading } \\
\text { Protocol } \\
\end{array}$ & Maintenance Dosage \\
\hline Infliximab $^{a}$ & Mouse/human chimeric antibody & TNF alpha & Intravenous & Yes & $\begin{array}{l}\text { 3-10 mg per kg every } \\
\text { 4-8 weeks }\end{array}$ \\
\hline Etanercept ${ }^{b}$ & Receptor fusion protein & TNF alpha & Subcutaneous & No & $50 \mathrm{mg}$ weekly \\
\hline Adalimumabc $^{c}$ & Human antibody & TNF alpha & Subcutaneous & No & $40 \mathrm{mg}$ monthly \\
\hline Certolizumab pegold $^{\mathrm{d}}$ & $\begin{array}{c}\text { Pegylated Fab' fragment of } \\
\text { humanized antibody }\end{array}$ & TNF alpha & Subcutaneous & Yes & $\begin{array}{l}200 \text { mg every other week } \\
\text { or } 400 \mathrm{mg} \text { monthly }\end{array}$ \\
\hline Golimumabe & Human antibody & TNF alpha & Subcutaneous & No & $50 \mathrm{mg}$ per month \\
\hline Abatacept ${ }^{\mathrm{f}}$ & Receptor fusion protein & CD28/B7 T-cell costimulation & Intravenous & Yes & $\begin{array}{c}500-1,000 \mathrm{mg} \text { every } \\
4 \text { weeks according to weight }\end{array}$ \\
\hline Rituximabg & Mouse/human chimeric antibody & CD20+ B-cells & Intravenous & No & $\begin{array}{l}2 \text { separate } 1,000 \mathrm{mg} \text { doses } 2 \\
\text { weeks apart every } 6 \text { months }\end{array}$ \\
\hline Tocilizumab $^{\text {h }}$ & Humanized antibody & IL-6 receptor & Intravenous & No & 4-8 mg per kg every 4 weeks \\
\hline Anakinra $^{i}$ & Interleukin-1 receptor antagonist & IL-1 receptor & Subcutaneous & Yes & 100 mg daily \\
\hline \multicolumn{6}{|c|}{ 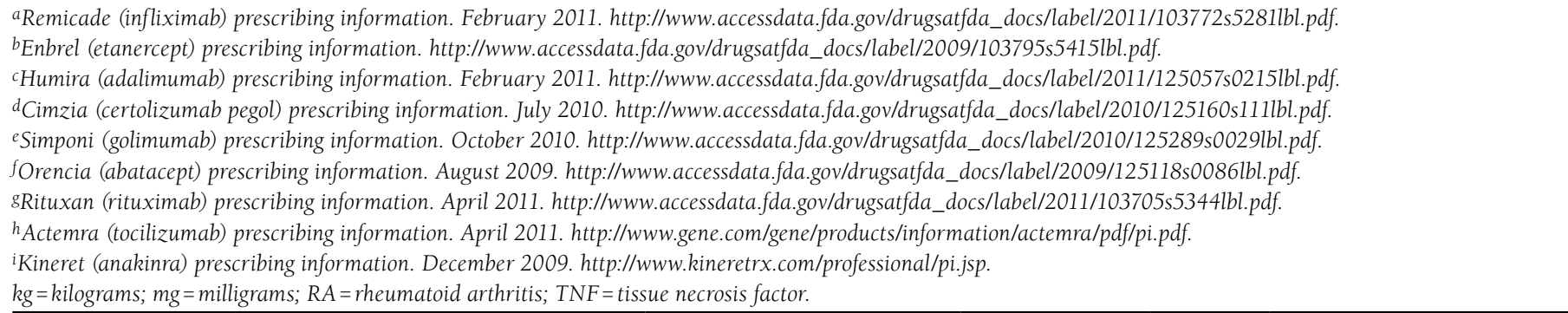 } \\
\hline
\end{tabular}

of osteoclasts in the bone to cause bone erosions. ${ }^{11}$ Advances in our understanding of the key cells (T cells, B cells) and inflammatory cytokines (TNF and IL-6) have provided therapeutic opportunities, which are now directly targeted by biologic agents approved for the treatment of RA (Table 1).

\section{Measuring Treatment Responses in Clinical Trials}

Clinical trials seeking to demonstrate the efficacy of a potential therapeutic in RA utilize several common outcomes. ${ }^{12}$ Clinical improvements in the symptoms of inflammation are usually documented using relative change in the American College of Rheumatology (ACR) 20 response and absolute change the Disease Activity Score (DAS28). ${ }^{13,14}$ The ACR 20 is defined as a reduction by $20 \%$ or more in the number of tender and swollen joints plus a $20 \%$ improvement in 3 of 5 of the following measures: pain, patient global assessment of disease activity, physician global assessment of disease activity, self-assessed physical disability, and acute phase reactants (erythrocyte sedimentation rate or C-reactive protein). ${ }^{13}$ Some studies will also report the ACR50 or ACR70, which are 50\% and 70\% improvements in the above measures. The DAS2 8 score is a weighted score of swollen joints count, tender joint counts, patient global assessment of disease activity, and acute phase reactants. ${ }^{14}$

Since the treatment of RA not only seeks to decrease symptoms of inflammatory arthritis, but also to prevent the joint damage that can ensue, many clinical trials seek to report indices of joint damage. ${ }^{15,16}$ Using plain film radiographs of the hands, there are several validated measures of joint damage in RA. The most commonly used tool in clinical trials is the Sharp Score, where higher scores indicate greater joint damage. ${ }^{15}$

\section{Tumor Necrosis Factor Inhibitors}

TNF-alpha is a key cytokine in the inflammatory process in RA. ${ }^{10,17}$ Biologic agents targeting TNF-alpha, called TNF inhibitors, were the first approved and most broadly used biologics for the treatment of RA. Currently, 5 TNF inhibitors are approved for use by the U.S. Food and Drug Administration (FDA): infliximab, etanercept, adalimumab, golimumab, and certolizumab pegol. In randomized clinical trials RCTs, all of these agents have been shown to be effective in reducing clinical signs of inflammation in RA patients who have failed therapy with synthetic disease-modifying agents by measures such as ACR20 and DAS28. ${ }^{18-25}$ Impressively, a significant number of patients in these RCTs also achieve ACR50 and ACR70 responses, and in some cases can achieve remission. Furthermore, TNF inhibitors are effective in reducing radiographic progression. Although the different TNF inhibitors have structural differences, no head-to-head clinical trials have been performed comparing the individual agents; therefore at this time, no conclusions can be made with regards to whether one TNF inhibitor is superior to another.

Per the FDA approval, infliximab should be used in combination with methotrexate. Multiple clinical trials have demonstrated that TNF inhibitors are more effective when combined 
with methotrexate. ${ }^{19,21,26}$ Multiple studies have demonstrated a significant benefit of early treatment with TNF inhibitors and methotrexate, suggesting that there may be a window of opportunity for early intervention that has lasting benefits to patients with regards to disease progression. ${ }^{26,27}$ Although these agents are clearly effective, some patients either do not respond or stop responding to a TNF inhibitor. ${ }^{28,29}$ Fortunately, multiple other biologic agents are also approved for treatment of RA patients.

Abatacept. Abatacept is a biologic agent that blocks T-cell activation through inhibition of CD28-B7 mediated costimulation of the T-cell. Structurally, abatacept is a recombinant, fully human fusion protein of human CTLA-4 and the Fc domain of human IgGl. Abatacept has been shown to be effective in treating clinical symptoms (improvement in ACR20, ACR50, and ACR70) in RA patients who have previously had an inadequate response to TNF inhibitors. ${ }^{30}$ Subsequent studies have also demonstrated that abatacept is effective in RA patients who have previously had an inadequate response to methotrexate (TNF inhibitor naive patients). ${ }^{31,32}$ Abatacept has also been shown to slow radiographic progression in RA patients..$^{30,33}$ Abatacept is approved by the FDA for treatment of patients with moderate to severe RA that have had an inadequate response to methotrexate or TNF inhibitors. More recently, a subcutaneous form of abatacept has been shown to have comparable efficacy and safety with the intravenous formulation in a noninferiority trial and has been approved by the FDA. ${ }^{34}$

Rituximab. Rituximab is a human/mouse chimeric antibody that targets CD20, a molecule that is found on the surface of $\mathrm{B}$-cells. The expression pattern of CD20 changes as B-cells differentiate from stem cells to B-cells and plasma cells. ${ }^{35}$ CD20 is found on pre B-cells, immature B-cells, activated B-cells, and memory B-cells but not plasma cells. ${ }^{35}$ The pilot studies demonstrating effectiveness of rituximab in RA rekindled the appreciation of the importance of the B-cell lineage in the pathogenesis of RA. ${ }^{36}$ The DANCER study and the REFLEX study are important RCTs that have demonstrated a clinical benefit in RA patients with an inadequate response to methotrexate or TNF inhibitors, respectively. 37,38 Furthermore, it has been demonstrated that rituximab delays radiographic progression in RA patients. ${ }^{38}$ Subsequent studies have demonstrated the feasibility of administering repeated courses of rituximab at 6-month intervals. ${ }^{39}$ Accordingly, the FDA has approved rituximab for the treatment of patients with moderate to severe RA that have had an inadequate response to TNF inhibitors.

Tocilizumab. Tocilizumab is a humanized antibody directed against the IL-6 receptor, an inflammatory cytokine that is produced by and targets a large number of cells relevant to RA pathophysiology. ${ }^{40}$ Macrophages, B-cells, T-cells, fibroblasts, and other cells are capable of producing IL-6. Osteoclasts, B-cells, T-cells, hematopoietic stem cells, and hepatocytes are capable of responding to IL- 6 through the IL-6 receptor. ${ }^{40}$ The OPTION trial demonstrated the efficacy of tocilizumab in treating clinical symptoms of RA in patients with an inadequate response to methotrexate, and the RADIATE trial demonstrated the efficacy of tocilizumab in treating clinical symptoms of RA in patients with an inadequate response to TNF inhibitors. ${ }^{41,42}$ Lastly, the LITHE trial also confirmed the clinical benefit of tocilizumab in RA treatment, demonstrating that tocilizumab also delays radiographic progression in RA patients. ${ }^{43}$ Accordingly, the FDA has approved tocilizumab for the treatment of patients with moderate to severe RA that have had an inadequate response to TNF inhibitors.

\section{Adverse Events}

The biologic agents approved for the treatment of RA result in rapid improvement in clinical symptoms, and all delay radiographic progression. However, biologic agents must be used judiciously and with consideration of the potential adverse effects that may occur. All biologic agents carry an increased risk of infections. RA patients using these medications who present with fevers should be evaluated by a physician to determine the source of the fever, and antibiotics should be administered, if appropriate. Given the risks of infections by all of these agents, it is not recommended that patients be treated with simultaneous combinations of biologic agents. Additional potential side effects include injection site reactions in subcutaneously administered agents. Furthermore, the intravenous biologic agents can have infusion reactions ranging from minor to life-threatening. All patients being considered for biologic agents should be screened annually for tuberculosis (TB) using a tuberculin skin test or the interferon-gamma release TB blood tests. All patients on biologic agents should receive a pneumococcal vaccination, annual influenza vaccination, and hepatitis B vaccination. Finally, for patients on biologics, all live vaccinations should be avoided in patients and household contacts.

Other considerations differ depending on the class of biologic agents. TNF inhibitors are contraindicated in patients with hepatitis B, multiple sclerosis or demyelinating diseases, or congestive heart failure (New York Heart Association class III-IV). It remains controversial as to whether TNF inhibitors are associated with an increased risk of malignancies. Rituximab has been associated with transient neutropenia and hypogammaglobulinemia. ${ }^{44}$ While opportunistic infections have been reported in case reports with all the biologic agents, progressive multifocal leukoencephalopathy, due to JC virus, has been reported in rheumatic patients receiving rituximab at the case report level. ${ }^{45}$ Finally neutropenia, liver function abnormalities, thrombocytopenia, and elevated lipids have been observed in patients treated with tocilizumab in clinical trials. ${ }^{41,42}$ Long-term adverse effects of the biologic agents are not known, and RCTs are not optimal for the identification of rare adverse events. As we gain additional experience with biologic agents, physicians and other health care providers 
must remain alert to look for additional, previously unknown adverse events not identified in clinical trials.

\section{Conclusions}

Biologic agents directed at TNF-alpha, T-cell costimulation, B-cells, and IL- 6 are efficacious in clinical trials for the treatment of RA patients with an inadequate response to synthetic DMARDs. Furthermore, all of the biologic agents can delay radiographic progression, indicating the potential benefits in preventing long-term disability from joint damage in addition to the short-term disability from symptoms of inflammatory arthritis. The biologic agents are an important addition to the growing list of medications available for the treatment of RA, and when used judiciously are effective and relatively safe. However, these are potent medications with the potential for serious side effects. Therefore, patients being prescribed these agents should be carefully followed by physicians and other health care providers. By combining synthetic DMARDs and the available biologic agents, the management of RA has been transformed over the past 10 years offering RA patients great hope that they will experience clinical benefit and maintain productive, functional lives.

\section{Author}

SANDEEP K. AGARWAL, MD, PhD, is Assistant Professor of Medicine in the Department of Medicine, Section of Allergy, Immunology, and Rheumatology Biology of Inflammation Center at Baylor College of Medicine, Houston, Texas.

AUTHOR CORRESPONDENCE: Sandeep K. Agarwal, MD, $\mathrm{PhD}$, Department of Medicine, Section of Allergy, Immunology, and Rheumatology Biology of Inflammation Center, Baylor College of Medicine, One Baylor Plaza, Suite 672E, MS: BCM285, Houston, TX 77030. Tel.: 713.798.5626; Email: skagarwa@bcm.edu.

\section{DISCLOSURES}

This supplement was sponsored by PRIME Education, Inc. and Purdue University through an independent educational grant from Genentech, Biogen Idec, and Centocor Ortho Biotech Services LLC. Sandeep Agarwal received compensation from PRIME Education, Inc. for participating in the live continuing education activity on which this article is based and for writing the article. Agarwal reports payment for lectures and service on speaker bureaus from Genentech for programs on vasculitis.

\section{REFERENCES}

1. Lee DM, Weinblatt ME. Rheumatoid arthritis. Lancet. 2001;358(9285): 903-11.

2. Pullar T, Hunter JA, Capell HA. Sulphasalazine in rheumatoid arthritis: a double blind comparison of sulphasalazine with placebo and sodium aurothiomalate. Br Med J (Clin Res Ed). 1983;287(6399):1102-04. Available at: http://www.ncbi.nlm.nih.gov/pmc/articles/PMC1549364/pdf/bmjcred00575-0022.pdf. Accessed July 15, 2011.
3. Pinals RS. Sulfasalazine in the rheumatic disease. Semin Arthritis Rheum. 1988;17(4):246-59.

4. Weinblatt ME, Coblyn JS, Fox DA, et al. Efficacy of low-dose methotrexate in rheumatoid arthritis. N Engl J Med. 1985;312(13):818-22.

5. Williams HJ, Willkens RF, Samuelson CO, et al. Comparison of low-dose oral pulse methotrexate and placebo in the treatment of rheumatoid arthritis. A controlled clinical trial. Arthritis Rheum. 1985;28(7):721-30.

6. Cohen S, Cannon GW, Schiff M, et al. Two-year, blinded, randomized, controlled trial of treatment of active rheumatoid arthritis with leflunomide compared with methotrexate. Utilization of Leflunomide in the Treatment of Rheumatoid Arthritis Trial Investigator Group. Arthritis Rheum. 2001;44(9):1984-92. Available at: http://onlinelibrary.wiley.com/ doi/10.1002/1529-0131(200109)44:9\%3C1984\%:AID-ART346\%3E3.0.CO;2B/pdf. Accessed July 18, 2011.

7. Smolen JS, Kalden JR, Scott DL, et al. Efficacy and safety of leflunomide compared with placebo and sulphasalazine in active rheumatoid arthritis: a double-blind, randomised, multicentre trial. European Leflunomide Study Group. Lancet. 1999;353(9149):259-66.

8. Sharp JT, Strand V, Leung H, Hurley F, Loew-Friedrich I. Treatment with leflunomide slows radiographic progression of rheumatoid arthritis: results from three randomized controlled trials of leflunomide in patients with active rheumatoid arthritis. Leflunomide Rheumatoid Arthritis Investigators Group. Arthritis Rheum. 2000;43(3):495-505. Available at: http://onlinelibrary.wiley.com/doi/10.1002/1529-0131(200003)43:3\%3C495::AIDANR4\%3E3.0.CO;2-U/pdf. Accessed July 18, 2011.

9. Firestein GS. Evolving concepts of rheumatoid arthritis. Nature. 2003;423(6937):356-61.

10. Choy EH, Panayi GS. Cytokine pathways and joint inflammation in rheumatoid arthritis. N Engl J Med. 2001;344(12):907-16.

11. Gravallese EM, Goldring SR. Cellular mechanisms and the role of cytokines in bone erosions in rheumatoid arthritis. Arthritis Rheum. 2000;43(10):2143-51. Available at: http://onlinelibrary.wiley.com/ doi/10.1002/1529-0131(200010)43:10\%3C2143::AID-ANR1\%3E3.0.CO;2-S/ pdf. Accessed July 18, 2011.

12. Aletaha D, Landewe R, Karonitsch T, et al. Reporting disease activity in clinical trials of patients with rheumatoid arthritis: EULAR/ACR collaborative recommendations. Arthritis Rheum. 2008;59(10):1371-77. Available at: http://onlinelibrary.wiley.com/doi/10.1002/art.24123/pdf. Accessed July 18, 2011.

13. Felson DT, Anderson JJ, Boers M, et al. American College of Rheumatology. Preliminary definition of improvement in rheumatoid arthritis. Arthritis Rheum. 1995;38(6):727-35.

14. Prevoo ML, van Gestel AM, van THM, van Rijswijk MH, van de Putte LB, van Riel PL. Remission in a prospective study of patients with rheumatoid arthritis. American Rheumatism Association preliminary remission criteria in relation to the disease activity score. Br J Rheumatol. 1996;35(11):1101-05. Available at: http://rheumatology.oxfordjournals.org/ content/35/11/1101.full.pdf. Accessed July 18, 2011.

15. Sharp JT, Lidsky MD, Collins LC, Moreland J. Methods of scoring the progression of radiologic changes in rheumatoid arthritis. Correlation of radiologic, clinical and laboratory abnormalities. Arthritis Rheum. 1971;14(6):706-20.

16. Larsen A. Radiological grading of rheumatoid arthritis. An interobserver study. Scand J Rheumatol. 1973;2(3):136-38.

17. Brennan FM, Chantry D, Jackson AM, Maini RN, Feldmann M. Cytokine production in culture by cells isolated from the synovial membrane. J Autoimmun. 1989;2(Suppl):177-86.

18. Maini R, St Clair EW, Breedveld F, et al. Infliximab (chimeric antitumour necrosis factor alpha monoclonal antibody) versus placebo in rheumatoid arthritis patients receiving concomitant methotrexate: a randomised phase III trial. ATTRACT Study Group. Lancet. 1999;354(9194):1932-39. 
19. Weinblatt ME, Kremer JM, Bankhurst AD, et al. A trial of etanercept, a recombinant tumor necrosis factor receptor: Fc fusion protein, in patients with rheumatoid arthritis receiving methotrexate. N Engl J Med. 1999;340(4):253-59. Available at: http://www.nejm.org/doi/pdf/10.1056/ NEJM199901283400401. Accessed July 18, 2011.

20. Moreland LW, Baumgartner SW, Schiff MH, et al. Treatment of rheumatoid arthritis with a recombinant human tumor necrosis factor receptor (p75)-Fc fusion protein. N Engl J Med. 1997;337(3):141-47. Available at: http://www.nejm.org/doi/pdf/10.1056/NEJM199707173370301. Accessed July 18, 2011.

21. Weinblatt ME, Keystone EC, Furst DE, et al. Adalimumab, a fully human anti-tumor necrosis factor alpha monoclonal antibody, for the treatment of rheumatoid arthritis in patients taking concomitant methotrexate: the ARMADA trial. Arthritis Rheum. 2003;48(1):35-45. Available at: http:// onlinelibrary.wiley.com/doi/10.1002/art.10697/pdf. Accessed July 18, 2011.

22. Smolen J, Landewe RB, Mease P, et al. Efficacy and safety of certolizumab pegol plus methotrexate in active rheumatoid arthritis: the RAPID 2 study. A randomised controlled trial. Ann Rheum Dis. 2009;68(6):797-804. Available at: http://www.ncbi.nlm.nih.gov/pmc/articles/PMC2674556/pdf/ ard-68-06-0797.pdf. Accessed July 18, 2011.

23. Keystone E, Heijde D, Mason D, Jr., et al. Certolizumab pegol plus methotrexate is significantly more effective than placebo plus methotrexate in active rheumatoid arthritis: findings of a fifty-two-week, phase III, multicenter, randomized, double-blind, placebo-controlled, parallel-group study. Arthritis Rheum. 2008;58(11):3319-29. Available at: http://onlinelibrary.wiley. com/doi/10.1002/art.23964/pdf. Accessed July 18, 2011.

24. Keystone E, Genovese MC, Klareskog L, et al. Golimumab in patients with active rheumatoid arthritis despite methotrexate therapy: 52-week results of the GO-FORWARD study. Ann Rheum Dis. 2010;69(6):1129-35.

25. Smolen JS, Kay J, Doyle MK, et al. Golimumab in patients with active rheumatoid arthritis after treatment with tumour necrosis factor alpha inhibitors (GO-AFTER study): a multicentre, randomised, double-blind, placebo-controlled, phase III trial. Lancet. 2009;374(9685):210-21.

26. Breedveld FC, Weisman MH, Kavanaugh AF, et al. The PREMIER study: a multicenter, randomized, double-blind clinical trial of combination therapy with adalimumab plus methotrexate versus methotrexate alone or adalimumab alone in patients with early, aggressive rheumatoid arthritis who had not had previous methotrexate treatment. Arthritis Rheum. 2006;54(1):26-37. Available at: http://onlinelibrary.wiley.com/doi/10.1002/ art.21519/pdf. Accessed September 27, 2011.

27. Goekoop-Ruiterman YP, de Vries-Bouwstra JK, Allaart CF, et al. Clinical and radiographic outcomes of four different treatment strategies in patients with early rheumatoid arthritis (the BeSt study): a randomized, controlled trial. Arthritis Rheum. 2005;52(11):3381-90. Available at: http://onlinelibrary. wiley.com/doi/10.1002/art.21405/pdf. Accessed July 18, 2011.

28. Agarwal SK, Maier AL, Chibnik LB, et al. Pattern of infliximab utilization in rheumatoid arthritis patients at an academic medical center. Arthritis Rheum. 2005;53(6):872-78. Available at: http://onlinelibrary.wiley.com/ doi/10.1002/art.21582/pdf. Accessed September 15, 2011

29. Agarwal SK, Glass RJ, Shadick NA, et al. Predictors of discontinuation of tumor necrosis factor inhibitors in patients with rheumatoid arthritis. $J$ Rheumatol. 2008;35(9):1737-44. Available at: http://www.ncbi.nlm.nih.gov/ pmc/articles/PMC2756035/pdf/nihms132311.pdf. Accessed September 15, 2011.

30. Genovese MC, Becker JC, Schiff M, et al. Abatacept for rheumatoid arthritis refractory to tumor necrosis factor alpha inhibition. N Engl J Med. 2005;353(11):1114-23. Available at: http://www.nejm.org/doi/pdf/10.1056/ NEJMoa050524. Accessed July 18, 2011.

31. Genant HK, Peterfy CG, Westhovens R, et al. Abatacept inhibits progression of structural damage in rheumatoid arthritis: results from the long-term extension of the AIM trial. Ann Rheum Dis. 2008;67(8):1084-89. Available at: http://www.ncbi.nlm.nih.gov/pmc/articles/PMC2569144/pdf/ARD-67-081084.pdf. Accessed July 18, 2011.
32. Kremer JM, Genant HK, Moreland LW, et al. Results of a two-year followup study of patients with rheumatoid arthritis who received a combination of abatacept and methotrexate. Arthritis Rheum. 2008;58(4):953-63. Available at: http://onlinelibrary.wiley.com/doi/10.1002/art.23397/pdf Accessed July 18, 2011.

33. Westhovens R, Robles M, Ximenes AC, et al. Clinical efficacy and safety of abatacept in methotrexate-naive patients with early rheumatoid arthritis and poor prognostic factors. Ann Rheum Dis. 2009;68(12):1870-77. Available at: http://www.ncbi.nlm.nih.gov/pmc/articles/PMC2770104/pdf/ard-68-121870.pdf. Accessed July 18, 2011.

34. Genovese M, Covarrubias A, Leon G, et al. Subcutaneous abatacept versus intravenous abatacept: a phase IIIb non-inferiority study in patients with an inadequate response to methotrexate. Arthritis Rheum. 2011;63(10):285464.

35. St Clair EW, Tedder TF. New prospects for autoimmune disease therapy: B cells on deathwatch. Arthritis Rheum. 2006;54(1):1-9. Available at: http:// onlinelibrary.wiley.com/doi/10.1002/art.21525/pdf. Accessed July 18, 2011.

36. Edwards JC, Szczepanski L, Szechinski J, et al. Efficacy of B-cell-targeted therapy with rituximab in patients with rheumatoid arthritis. N Engl J Med. 2004;350(25):2572-81. Available at: http://www.nejm.org/doi/pdf/10.1056/ NEJMoa032534. Accessed July 18, 2011.

37. Emery P, Fleischmann R, Filipowicz-Sosnowska A, et al.; DANCER Study Group. The efficacy and safety of rituximab in patients with active rheumatoid arthritis despite methotrexate treatment: results of a phase IIB randomized, double-blind, placebo-controlled, dose-ranging trial. Arthritis Rheum. 2006;54(5):1390-400. Available at: http://onlinelibrary.wiley.com/ doi/10.1002/art.21778/pdf. Accessed September 27, 2011.

38. Cohen SB, Emery P, Greenwald MW, et al. Rituximab for rheumatoid arthritis refractory to anti-tumor necrosis factor therapy: results of a multicenter, randomized, double-blind, placebo-controlled, phase III trial evaluating primary efficacy and safety at twenty-four weeks. Arthritis Rheum. 2006;54(9):2793-806. Available at: http://onlinelibrary.wiley.com/ doi/10.1002/art.22025/pdf. Accessed July 18, 2011.

39. Keystone E, Fleischmann R, Emery P, et al. Safety and efficacy of additional courses of rituximab in patients with active rheumatoid arthritis: an open-label extension analysis. Arthritis Rheum. 2007;56(12):3896-908 Available at: http://onlinelibrary.wiley.com/doi/10.1002/art.23059/pdf. Accessed July 18, 2011.

40. Naka T, Nishimoto N, Kishimoto T. The paradigm of IL-6: from basic science to medicine. Arthritis Res. 2002;4(Suppl 3):S233-S242.

41. Smolen JS, Beaulieu A, Rubbert-Roth A, et al. Effect of interleukin-6 receptor inhibition with tocilizumab in patients with rheumatoid arthritis (OPTION study): a double-blind, placebo-controlled, randomised trial. Lancet. 2008;371(9617):987-97.

42. Emery P, Keystone E, Tony HP, et al. IL-6 receptor inhibition with tocilizumab improves treatment outcomes in patients with rheumatoid arthritis refractory to anti-tumour necrosis factor biologicals: results from a 24 -week multicentre randomised placebo-controlled trial. Ann Rheum Dis. 2008;67(11):1516-23.

43. Kremer JM, Blanco R, Brzosko M, et al. Tocilizumab inhibits structural joint damage in rheumatoid arthritis patients with inadequate responses to methotrexate: results from the double-blind treatment phase of a randomized placebo-controlled trial of tocilizumab safety and prevention of structural joint damage at one year. Arthritis Rheum. 2011;63(3):609-21.

44. Tesfal D, Ajeganova S, Hagglund H, et al. Late-onset neutropenia following rituximab therapy in rheumatic diseases: association with B-lymphocyte depletion and infections. Arthritis Rheum. 2011;63(8):2209-14.

45. Calabrese LH, Molloy ES. Progressive multifocal leucoencephalopathy in the rheumatic diseases: assessing the risks of biological immunosuppressive therapies. Ann Rheum Dis. 2008;67(Suppl 3):iii64-iii65. 